\title{
Comparative Performance of Microbial Lipases Immobilized on Magnetic Polysiloxane Polyvinyl Alcohol Particles
}

\author{
Laura Maria Bruno ${ }^{1}$, José Luiz de Lima Filho ${ }^{2}$ and Heizir Ferreira de Castro ${ }^{3}$ \\ ${ }^{1}$ Embrapa Agroindústria Tropical; Rua Dra. Sara Mesquita, 2270; Imbruno@cnpat.embrapa.br; 60511-110; \\ Fortaleza - CE - Brasil. ${ }^{2}$ Departmento de Bioquímica; Universidade Federal de Pernambuco; 50670-420; Recife - \\ PE - Brasil. ${ }^{3}$ Escola de Engenharia de Lorena; Universidade de São Paulo; C. P.: 116; 12600-970; Lorena - SP - \\ Brasil
}

\begin{abstract}
Microbial lipase from Mucor miehei and Candida rugosa were immobilized by covalent binding onto magnetized polysiloxane polyvinyl alcohol particles (POS-PVA). The resulting immobilized derivatives were evaluated in aqueous solution (olive oil hydrolysis) and organic solvent (butyl butyrate synthesis). Higher catalytic activities were found when the coupling procedure was made with $\mathrm{M}$. miehei lipase. Immobilized M. miehei lipase also showed a better operational stability and a higher half-life than C. rugosa lipase after the successive batches of esterification. The performance of $\mathrm{C}$. rugosa immobilized derivative was constrained by the low lipase loading used in the immobilizing step. Further information regarding the both immobilized derivatives was also obtained through chemical composition (FTIR).
\end{abstract}

Key words: Candida lipase, Mucor lipase, hybrid matrix, immobilization

\section{INTRODUCTION}

Lipase immobilization is usually considered as a technique that increases the operational stability of the enzymes due to several traits: the enzyme is dispersed and cannot aggregate (Castro and Anderson, 1995), interaction with the external interfaces is prevented and the enzyme structure may be rigidified by the covalent attachment (Faber, 1997). Moreover, the enzyme immobilization provides a favorable approach for easy enzyme recovery for its recycled use (Dey et al., 2003). Thus, exploiting good immobilization carriers has been an attractive work for the enzyme engineering. Several methods for lipase immobilization have been reported, including deposition on to solid supports (Oliveira et al., 2000; Person et al., 2000), covalent binding (Soares et al., 1999) and entrapment within a polymer matrix or hydrophobic sol-gel materials (Keeling-Tucker et al., 2000; Reetz et al., 1998). The latter method can be applied to a variety of enzymes, yielding immobilized systems with 80fold esterification activity compared to the free enzyme (Reetz et al., 1996).

The sol-gel process involves the transition of a system from a liquid "sol" (mostly colloidal) into a solid "gel" phase (Reetz et al., 1996). According to Ingersoll and Bright (1997), it is a simple threestep reaction sequence. In the first step, hydrolysis of a metal or semi-metal alkoxide precursor forms the hydroxylated product and the corresponding

\footnotetext{
${ }^{*}$ Author for correspondence
} 
alcohol. Next, the condensation between an unhydrolyzed alkoxide group and a hydroxyl group or between the two hydroxyls eliminates the solvent (water and alcohol) and forms a colloidal mixture, called the sol. In the third and final step, the polycondensation between these colloidal sols and additional networking eventually results in a porous, glasslike, three-dimensional network.

The sol-gel technique has been employed especially to the protein entrapment, since it is chemically inert, thermally stable and transparent, enabling spectroscopic monitoring of the entrapped sample (Diaz and Peinado, 1997). However, the major disadvantage of this kind of immobilization is that it requires a careful control of pore size to avoid the mass-transfer problems and leakage of the biological recognition element (Diaz and Peinado, 1997). Thus, the covalent immobilization could be an attractive alternative to overcome such limitations.

It has been reported that the sol-gel technique is also an excellent method to prepare the hybrid materials. Silica glass beads were synthesized by the alkoxide sol-gel process and used as solid phase in ELISA for the experimental plague studies (Barros et al., 2002; Coelho et al., 2003). Using similar methodology, Bruno (2003) employed tetraethoxysilane (TEOS) and polyvinyl alcohol (PVA) for the matrix formation, followed by the activation with glutaraldehyde to render more biocompatible surface for the covalent immobilization. The resulting polysiloxanepolyvinyl alcohol (POS-PVA) composite combined the PVA property to covalently retain the proteins, via glutaraldehyde, with excellent optical, thermal and chemical stability of the host silicon oxide matrix. Moreover, the hybrid matrix can be conjugated to magnetite $\left(\mathrm{Fe}_{3} \mathrm{O}_{4}\right)$ that enables to achieve a rapid separation in a magnetic field. The magnetic support was first applied to immobilized the enzymes in 1973 (Robinson et al., 1973). Besides the merits of other solid carriers, the enzymes immobilized by the magnetic materials can be more easily separated from a reaction system, and stabilized in a fluidized-bed reactor.

Here, by using the lipase as a model enzyme, this paper reports the use of the magnetic POS-PVA particles as the immobilizing support for the lipase from Mucor miehei (MML) and Candida rugosa (CRL), employing the glutaraldehyde as the bifunctional agent to promote the covalent attachment. Both the lipase preparations have received much attention due to its high activity and broad specificity (Sharma et al., 2001; Benjamim and Pandey, 2001).

\section{MATERIALS AND METHODS}

\section{Materials}

Mucor miehei lipase was kindly donated by Novozymes (Araucaria, PR, Brazil). Candida rugosa lipase (CRL type VII) was purchased from Sigma Co (St. Louis, MO, USA). Tetraethoxysilane (TEOS) was from Aldrich Chemical Co. (Milwaukee, WI, USA). Glutaraldehyde $(25 \%$ w/v), hydrochloric acid (minimum 36\%), ethanol (minimum 99\%) and polyvinyl alcohol PVA (MW 72,000) were supplied by Reagen (Rio de Janeiro, RJ, Brazil). Butyric acid and $n$-butanol were purchased from Merck (Darmstadt, Germany). Solvents were standard laboratory grade (Synth, São Paulo, SP, Brazil). Heptane was dried with metallic sodium and used as solvent for all experiments. The substrates for esterification reactions were dehydrated with molecular sieves with $0.32 \mathrm{~cm}$ in diameter (aluminum sodium silicate, type 13XBHD Chemicals, Toronto, Canada) previously activated in oven at $350^{\circ} \mathrm{C}$ for $6 \mathrm{~h}$.

\section{Polysiloxane-polyvinyl alcohol synthesis}

A POS-PVA hybrid composite was prepared by the hydrolysis and polycondensation of TEOS as described by Barros et al. (2002). The reagents TEOS $(5 \mathrm{ml})$, ethanol $(5 \mathrm{ml})$, and PVA solution $2 \%(\mathrm{w} / \mathrm{v})(6 \mathrm{ml})$ were carefully mixed and stirred for $5 \mathrm{~min}$ at $60{ }^{\circ} \mathrm{C}$, followed by the addition of two or three drops of the concentrated $\mathrm{HCl}$, in order to catalyze the reaction. After an incubation period of $40 \mathrm{~min}$, the material was transferred to the microwells of the tissue culture plates and kept at $25{ }^{\circ} \mathrm{C}$ until complete gel solidification (formation of the interpenetrated network of POS-PVA). Then, the spheres were ground in a ball mill to attain $37 \mu \mathrm{m}$ diameter particles, which were magnetized according to Carneiro-Leão et al. (1991) based on the co-precipitation from a solution of $\mathrm{FeCl}_{3} \cdot 6 \mathrm{H}_{2} \mathrm{O}$ and $\mathrm{FeCl}_{2} \cdot 4 \mathrm{H}_{2} \mathrm{O}$. Activation of POS-PVA particles was carried out with $2.5 \%(\mathrm{w} / \mathrm{v})$ glutaraldehyde at $\mathrm{pH} 7.0$ for $1 \mathrm{~h}$ at room temperature, followed by exhaustively washings with distilled water. 
Lipase immobilization onto POS-PVA particles The activated POS-PVA particles were soaked into hexane under stirring $(100 \mathrm{rpm})$ for $1 \mathrm{~h}$ at $25^{\circ} \mathrm{C}$. Then, the excess of hexane was removed and 85 units of hydrolytic activity/g support for both the lipases (CRL and MML) were added to the support. Lipase-support systems were maintained in contact for $16 \mathrm{~h}$ at $4^{\circ} \mathrm{C}$ under the static conditions. The immobilized lipase derivatives were filtered (nylon membrane 62HD from Scheiz Seidengazefabrik AG, Thal Schweiz, Switzerland) and thoroughly rinsed with hexane.

\section{Protein assay}

The protein was determined according to Bradford's method (Bradford, 1976), using the bovine serum albumin (BSA) as the standard. The amount of bound protein was determined indirectly from the difference between the amount of the protein introduced into the coupling reaction mixture and the amount of protein in the filtrate and the washing solutions.

\section{Hydrolytic activity determination}

The hydrolytic activities of the free and immobilized lipase derivatives were assayed by the olive oil emulsion method according to the modification proposed by Soares et al. (1999). The substrate was prepared by mixing $50 \mathrm{ml}$ of olive oil with $50 \mathrm{ml}$ of gum arabic solution $(7 \% \mathrm{w} / \mathrm{v})$. The reaction mixture containing $5 \mathrm{ml}$ of the emulsion, $4 \mathrm{ml}$ of $100 \mathrm{mM}$ sodium phosphate buffer ( $\mathrm{pH} 7.00)$ and either free $\left(1 \mathrm{ml}, 5 \mathrm{mg} \cdot \mathrm{ml}^{-1}\right)$ or immobilised $(250 \mathrm{mg})$ lipase was incubated for $5 \mathrm{~min}$ at $37^{\circ} \mathrm{C}$. The reaction was stopped by the addition of $10 \mathrm{ml}$ of acetone-ethanol solution (1:1). The liberated fatty acids were titrated with $25 \mathrm{mM}$ potassium hydroxide solution in the presence of phenolphthalein as indicator. One unit (U) of the enzyme activity was defined as the amount of enzyme which liberated $1 \mu \mathrm{mol}$ of the free fatty acid/min under the assay conditions $\left(37^{\circ} \mathrm{C}, \mathrm{pH} 7.0,150 \mathrm{rpm}\right)$. The analyses of the hydrolytic activities carried out on the lipase loading solution and immobilized preparations were used to determine the coupling yield $(\eta \%)$ according to the equation 1 .

$$
\eta(\%)=\frac{U s}{U_{0}} \times 100
$$

where: $U s=$ total enzyme activity recovered in the support and $U_{o}=$ enzyme units offered for the immobilization.

\section{Synthetic activity determination}

The reaction systems consisted of heptane $(20 \mathrm{ml})$, $n$-butanol (300 mM), butyric acid $(300 \mathrm{mM})$ and immobilized lipase derivatives $(0.5 \mathrm{~g}$, d.wt). Molecular sieves were used to remove the water. The mixture was incubated at $37^{\circ} \mathrm{C}$ for $24 \mathrm{~h}$ with the continuous shaking at $150 \mathrm{rpm}$. The butanol consumed and butyl butyrate were determined by the gas chromatography using a $6 \mathrm{ft} 5 \%$ DEGS on Chromosorb WHP, 80/10 mesh column (Hewlett Packard, Palo Alto, CA, USA) and hexanol as an internal standard. Esterification activity was expressed as $\mu \mathrm{mol}$ of formed butyl butyrate. $\mathrm{g}^{-1} \cdot \mathrm{min}^{-1}$ of the dry support (Pereira et al, 2003).

\section{Operational stability of the immobilized lipase derivatives}

The operational stability of both the immobilized derivatives was assayed by using $0.5 \mathrm{~g}$ (d.wt) of immobilized lipase in butyl butyrate synthesis in the successive batches. At the end of each batch, the immobilized lipase was removed from the reaction medium and washed with hexane to remove any substrate or product retained in the matrix. One hour later (length of time required for evaporation of the solvent), the immobilized lipase was introduced into a fresh medium. The activities were estimated at the end of each cycle and expressed as $\mu$ mol. $\mathrm{g}^{-1} \cdot \mathrm{min}^{-1}$ of the catalyst. The biocatalyst half-life time $\left(\mathrm{t}_{1 / 2}\right)$ was determined by applying the inverted linear decay model (Pereira et al., 2003).

\section{Fourier Transform Infrared Spectroscopy (FTIR)}

The samples of the free lipase and immobilized derivatives were submitted to the FTIR analysis (Spectrophotometer FTIR BOMEM MB-100). The spectra were obtained in the 400 to $4000 \mathrm{~cm}^{-1}$ wavelength range for the evaluation of the immobilization procedures. 


\section{RESULTS AND DISCUSSION}

Table 1 summarizes the results for the covalent immobilization of $M$. miehei (MML) and $C$. rugosa (CRL) lipase on POS-PVA, regarding the protein and activity recoveries. Similar protein recovered and coupling yields $(\approx 50 \%)$ were obtained for both the lipase derivatives. Different behavior was found when the immobilized derivatives were tested in the organic media, using the synthesis of butyl butyrate as the reaction model (Table 2). This reaction was selected because it gave measurable results with the maximum accuracy in a short span of time and with a minimum amount of lipase. In addition, this reaction system has been used by Soares et al. (1999); Oliveira et al. (2000) and Pereira et al. (2003). Under these conditions the MML immobilized on the POS-PVA showed higher synthetic activity than the CRL immobilized derivative (Table 2). In the case of the MML immobilized, the maximum conversion of $n$ butanol into butyl butyrate was $207 \mathrm{mM}$ after $24 \mathrm{~h}$ reaction. This value was significantly lower $(76 \mathrm{mM})$ when the CRL immobilized was used.

This was an expected behavior since the properties of the immobilized preparations were governed by the properties of both the enzyme and the carrier material. The interaction between the two provided an immobilized enzyme with specific chemical, biochemical, mechanical and kinetic properties (Tischer and Kasche, 1999), which explained the differences observed between the MML and CRL immobilized derivatives. Similar behavior was also observed by Pereira et al. (2003) working with $C$. rugosa and porcine pancreas lipases immobilized on the chitosan beads. These authors obtained the highest protein and activity recovered for the microbial lipase.

Table 1 - Protein recovery, hydrolytic activities and coupling yield for $M$. miehei and C. rugosa lipase immobilization on POS-PVA

\begin{tabular}{cccc}
\hline Lipase & $\begin{array}{c}\text { Bound Protein } \\
(\boldsymbol{\%})\end{array}$ & $\begin{array}{c}\text { Hydrolytic Activity } \\
(\mathbf{U} / \mathbf{m g})\end{array}$ & $\begin{array}{c}\text { Coupling Yield } \\
(\boldsymbol{\%})\end{array}$ \\
\hline MML & 56.7 & 43.89 & 51.44 \\
CRL & 63.2 & 46.29 & 53.92 \\
\hline
\end{tabular}

Lipase loading: 85 units/gram of support

Table 2 - Synthesis of butyl butyrate catalyzed by M. miehei and C. rugosa immobilized lipase derivatives on POSPVA

\begin{tabular}{|c|c|c|c|}
\hline Lipase & $\begin{array}{c}\text { Butanol } \\
\text { Conversion } \\
(\%)\end{array}$ & $\begin{array}{l}\text { Butyl Butyrate } \\
\text { (mM) }\end{array}$ & $\begin{array}{l}\text { Esterification Activity } \\
\quad\left(\mu \mathrm{mol} \cdot \mathrm{g}^{-1} \cdot \mathrm{min}^{-1}\right)\end{array}$ \\
\hline MML & 69.00 & 207 & 287.55 \\
\hline CRL & 25.33 & 76 & 116.95 \\
\hline
\end{tabular}

In addition, in this work similar loading of the free enzymes based on the units of hydrolytic activity (85 units/g support) was used for both the lipase preparations. The enzyme loading is a very important parameter that also controls the activity of the immobilized derivatives, particularly with the lipases, which have strong affinity for the surfaces. Therefore, for better performance of the immobilized lipase, it is suggested to optimize the lipase loading (units/g support) for each source and for each particular support, since at low enzyme loading, the lipase attempts to maximize its contact with the surface, which results in a loss of the conformation and consequently, in a reduction of the activity (Gomes et al., 2004). At higher loading, lesser area is available for the lipase to spread itself, more of its active conformation is retained, and the loss in the activity is reduced. Under the conditions used in this work, it seemed that for the MML no depression of the efficiency at low lipase loading was observed, whereas for the CRL there could be a much stronger interaction between the $C$. rugosa lipase and the support, which led to greater activity loss at low loading due to lipase spreading. Results described in the literature indicated that $C$. rugosa lipase required high loading per gram of the support (usually $250 \mathrm{U} / \mathrm{g}$ ) to attain the active and stable immobilized derivatives (Soares et al, 2002; Pereira et al, 2003; Gomes et al, 2004). Therefore, 
the lower performance of $C$. rugosa immobilized derivative could be related to the low lipase loading used in the immobilizing step. In view of these results, lipase loading for the CRL on POSPVA should be further determined.

To confirm the superiority of the enzyme-support complex obtained with the MML, investigations were also carried out to determine the operational stability for both the immobilized derivatives to perform the esterification reactions. The retention of the biocatalyst activity after the repeated use was assessed in terms of butyl butyrate formation during the consecutive batches (Fig. 1). In the first batch run, the ester yields were high for both the lipase preparations and declined in the subsequent reuses. For the MML the derivative such reduction was slower than for the CRL, which showed a sharp decline. Such profiles corresponded to the biocatalysts half-life $\left(\mathrm{t}_{1 / 2}\right)$ of 88.2 and $50.1 \mathrm{~h}$, respectively (Fig. 1). This better performance for $M$. miehei in comparison with $C$. rugosa in the immobilized form was also observed by Manjon et al. (1991) when testing the Celite as a support for the immobilization of the same lipase sources in the ester hydrolysis (olive oil) and synthesis (ethyl butyrate). According to these workers, both the hydrolytic and synthetic activities were higher for M. miehei immobilized lipase.

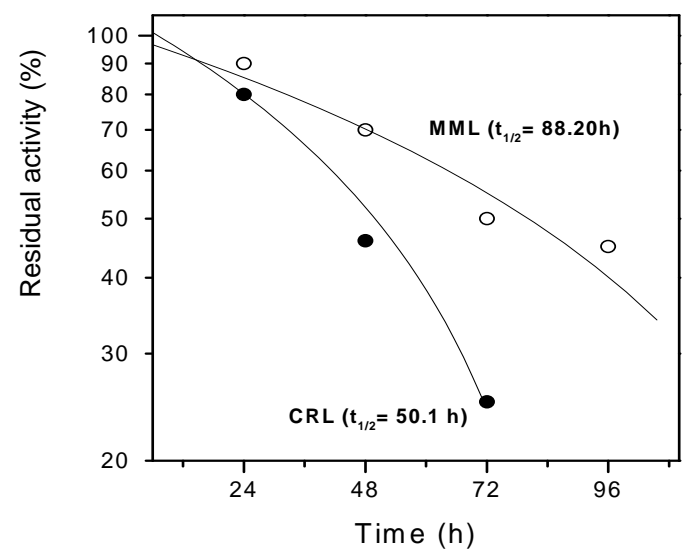

Figure 1 - Batch operational stability tests for MML and CRL immobilized on POS- PVA. Initial synthetic activities were: $287.55 \mu \mathrm{mol} . \mathrm{g}^{-1} \cdot \mathrm{min}^{-1}$ for MML and $116.95 \mu \mathrm{mol} . \mathrm{g}^{-1} \cdot \mathrm{min}^{-1}$ for CRL.

The efficiency of the methodology in relation to the free lipase incorporation on the POS-PVA was also assessed by the infrared spectroscopy. Figures $2 \mathrm{a}$ and $\mathrm{b}$ show a set of spectra for the free lipase preparations and immobilized derivatives. As observed, both the free lipases showed a typical spectrum of the proteins, with the absorption bands associated with their characteristic amide group $(\mathrm{CONH})$. Between the wave number range from $1600-1700 \mathrm{~cm}^{-1}$, there was the amide I band, due to the double bond $\mathrm{CO}$ stretching, the $\mathrm{CN}$ stretching and NH bending (Stuart et al., 1996). For the immobilized systems, the spectra showed typical amide bands of the lipase, but they were less intense than the free lipases due to their fixation on the solid support. No additional bands in the spectra for the immobilized derivatives were observed since the covalent bond between the enzyme and support was of the same nature of the typical protein bonds. Moreover, the glutaraldehyde, used as activation agent in the immobilization procedure, is a bifunctional reactive compound capable of reacting with the surface $\mathrm{OH}$ groups of the support and the amine groups of enzyme (Geng et al., 2003), resulting in amide bonds similar to the present in the free proteins. 


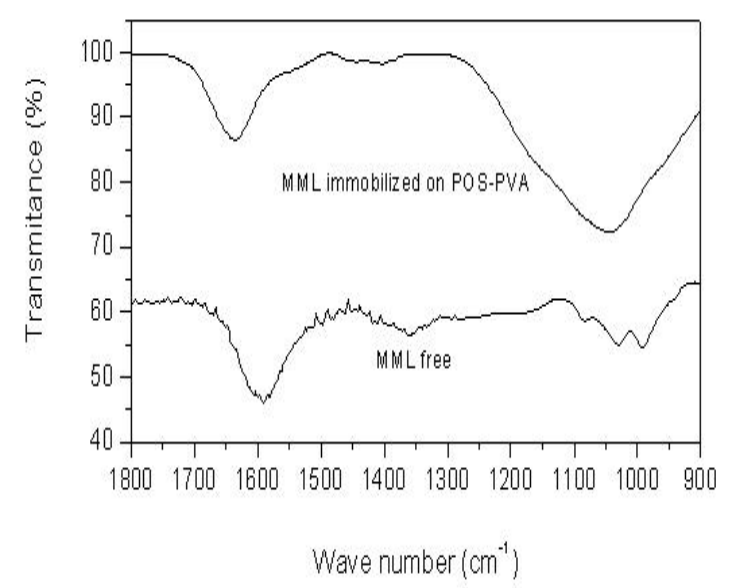

A

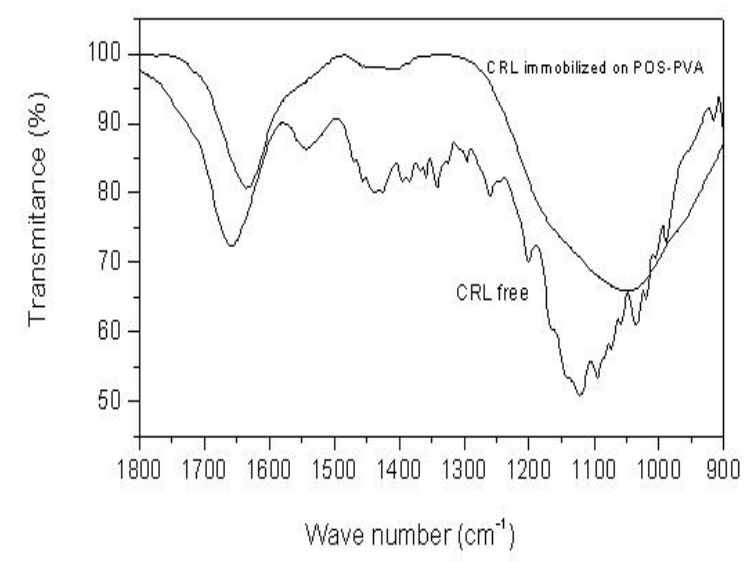

B

Figure 2 - FTIR spectra for the free lipase and immobilized derivatives on POS-PVA. (A) Mucor miehei and (B) Candida rugosa lipase.

\section{CONCLUSIONS}

From the results it could be concluded that the magnetized polysiloxane polyvinyl alcohol composite was an attractive support for immobilizing the lipases from different sources. Of the two sources tested, better performance was found when the immobilized derivative was prepared with the MML. Similar behavior for the CRL could be expected to be achieved by increasing the lipase loading in the immobilization step. To improve the esterification performance, it would be necessary to study the parameters that influence this synthesis, such as the reactants ratio molar, temperature and strategies for the removal of the water formed as the by-product.

\section{ACKNOWLEDGMENTS}

The authors gratefully acknowledge the financial assistance of CNPq (Conselho Nacional de Desenvolvimento Científico).

\section{RESUMO}

Lipases microbianas de Mucor miehei e Candida rugosa foram imobilizadas por ligação covalente em partículas magnetizadas de polisiloxano-álcool polivinílico (POS-PVA). Os derivados imobilizados resultantes foram avaliados em solução aquosa (hidrólise de azeite de oliva) e em solvente orgânico (síntese de butirato de butila). 
As maiores atividades catalíticas foram encontradas quando o procedimento de ligação foi realizado com lipase de $M$. miehei. O derivado imobilizado de lipase de $M$. miehei também apresentou melhores resultados de estabilidade operacional e tempo de meia-vida do que o de lipase de C. rugosa, após sucessivas bateladas de esterificação. $\mathrm{O}$ desempenho do derivado imobilizado de $C$. rugosa foi restringido pelo baixo carregamento de lipase usado na etapa de imobilização. Informações adicionais a respeito de ambos derivados imobilizados também foram obtidas através da composição química (FTIR).

\section{REFERENCES}

Barros, A. L.; Almeida, A. M. P.; Carvalho Jr., L. B. and Azevedo, W. M. (2002), Polysiloxane/PVAglutaraldehyde hybrid composite as solid phase for immunodetections by ELISA. Braz. J. Med. Biol. Res, 35, 459-463.

Bradford, M. M. (1976), A rapid and sensitive method for the quantification of microgram quantities of protein utilizing the principle of protein-dye binding. Anal. Biochem, 72, 248-254.

Benjamin, S.; Pandey, A. (2001), Isolation and characterization of three distinct forms of lipases from Candida rugosa produced in solid state fermentation. Braz. Arch. Biol. Techn., 44, 213-221.

Bruno, L. M. (2003), Desenvolvimento de sistemas enzimáticos (lipases) para aplicação na hidrólise e síntese de ésteres, DSc. thesis, Universidade Federal de Pernambuco, Recife, Brasil.

Castro, H.F. and Anderson, W.A. (1995), Fine chemicals by biotransformation using lipases. Quim. Nova, 18, 544-554.

Carneiro-Leão, A. M. A.; Oliveira, E. A. and Carvalho Jr, L. B. (1991), Immobilization of protein on ferromagnetic dacron. Appl. Biochem. Biotechnol., 31, 53-58.

Coelho, R. A. L.; Yamasaki, H.; Perez, E. and Carvalho Jr., L. B. (2003), The use of polysiloxane/polyvinyl alcohol beads as solid phase in IgG anti-toxocara canis detection using a recombinant antigen. Mem. Inst. Oswaldo Cruz, 98, 391-393.

Dey, G.; Singh, B.; Banerjee. (2203), R. Immobilization of $\alpha$-amylase produced by Bacillus circulans GRS 313. Braz. Arch. Biol. Techn., 46, 167-176.

Diaz, A. N. and Peinado, M. C. R. (1997), Sol-gel cholinesterase biosensor for organophosphorus pesticide fluorimetric analysis. Sens. and Actuators B, 38-39, 426-431.
Faber, K. (1997), Biotransformations in organic chemistry: A textbook. Springer-Verlag, Berlin, 402p.

Ingersoll, C. M. and Bright, F. V. (1997), Using sol-gelbased platforms for chemical sensors. Chem. Tech., 27, 26-31.

Geng, L., Li, N., Xiang, M., Wen, X., Xu, D., Zhao F. and Li, K. (2003), The covalent immobilization of trypsin at the galleries of layered g-zirconium phosphate. Colloid Surface B, 30, 99-109.

Gomes, F. M.; Pereira, E. B. and Castro, H. F. (2004), Immobilization of lipase on chitin and its use in nonconventional biocatalysis, Biomacromol. 5, 17-23.

Keeling-Tucker, T.; Rakic, M.; Spong, C.; Brennan, J. D. (2000), Controlling the material properties and biological activity of lipase within sol-gel derived bioglasses via organosilane and polymer doping). Chem. Mat., 12, 3695-3704.

Manjon, A.; Iborra, J. L.; Arocas, A. (1991). Shortchain ester synthesis by immobilized lipase in organic media. Biotechnol. Lett., 13, 339-344.

Oliveira, P. C.; Alves, G. M. and Castro, H. F. (2000), Síntese do butirato de n-butila empregando lipase microbiana imobilizada em copolímero de estirenodivinilbenzeno. Quim. Nova, 23, 632-636.

Pereira, E. B.; Zanin, G. M. and Castro, H. F. (2003), Immobilization and catalytic properties of lipase on chitosan for hydrolysis and esterification reactions. Braz. J. Chem. Eng. 20, 343-355.

Person, M.; Wehtje, E. and Adlercreutz, P. (2000), Immobilisation of lipases by adsorption and deposition: high protein loading gives lower water activity optimum. Biotechnol. Lett, 22, 1571-1575.

Reetz, M. T.; Zonta, A. and Simpelkamp, J. (1996), Efficient immobilization of lipases by entrapment in hydrophobic sol-gel materials. Biotechnol. Bioeng., 49, 527-534.

Reetz, M. T.; Zonta, A.; Vijayakrishnan, V. and Schimossek, K. (1998), Entrapment of lipases in hydrophobic magnetite-containing sol-gel materials: magnetic separation of heterogeneous biocatalysts. $J$. Mol. Catal. A: Chemical, 134, 251-258.

Robinson, P. J.; Dunnill, P. and Lilly, M. D. (1973), Properties of magnetic supports in relation to immobilized enzyme reactors. Biotechnol. Bioeng., 15, 603-606.

Sharma, R.; Chisti, Y.; Banerjee, U. C. (2001), Production, purification, characterization, and applications of lipases. Biotechnol. Advances, 19, 627-662.

Soares, C. M. F.; Castro, H. F.; Moraes, F. F. and Zanin, G. M. (1999), Characterization and utilization of Candida rugosa lipase immobilized on controlled pore silica. Appl. Biochem. Biotechnol. 77/79, 745757. 
Soares, C. M. F, Castro, H. F., Santana, M.H.A. and Zanin, G. M. (2002), Intensification of lipase performance for long term operation by immobilization on controlled pore silica in the presence of polythylene glycol., Appl. Biochem. Biotechnol, 98/100, p. 863-874.
Stuart, B. H.; George, W. O. and McIntyre, P. S. (1996), Modern Infrared Spectroscopy. John Wiley and Sons, Inc., Chichester, 200p.

Tischer, W. and Kasche, V. (1999), Immobilized enzymes: crystals or carriers? Trends in Biotechnol., 17, 326-335. 